\title{
EXAMINATION OF VIBRATION CHARACTERISTICS FOR WORKERS EXPOSED TO VIBRATION VIA THE FEET
}

\author{
Mallorie Leduc, ${ }^{1}$ Tammy Eger, ${ }^{1}$ Alison Godwin, ${ }^{1}$ Jim Dickey, ${ }^{2}$ Ron House ${ }^{3}$ \\ 1. Laurentian University, Sudbury, Ontario, Canada \\ 2. University of Western Ontario, London, Ontario, Canada \\ 3. University of Toronto and St. Michael's Hospital, Toronto, Ontario, Canada
}

\section{Introduction}

Prolonged exposure to hand-transmitted vibration has been shown to cause debilitating vascular, neurological, and musculoskeletal problems to the hand-arm ${ }^{1}$. Workers who are exposed to vibration via the feet could also be at risk for similar health problems ${ }^{2}$; however, limited research has examined the characteristics (frequency content, acceleration, amplitude) of vibration (from occupational sources) entering the body via the feet. In mining applications, vibration that enters the body via the feet has often been initiated with vibration from a hand-tool that has caused a working platform (that a worker is standing on) to vibrate. Therefore, the purpose of this study was to document the characteristics of vibration experienced at the feet under typical mining equipment operation.

\section{Methods}

Four types of underground mining equipment (locomotive; jumbo drill; raise platform wood; raise platform metal) that expose workers to vibration through the feet were tested. Equipment types were split into two categories, primary and secondary, depending on the origin of vibration. Transmitted vibration from a primary source originated from a motor responsible for moving a vehicle (locomotive). The vibration exposure at the feet was classified as a secondary source exposure if the vibration was originally generated by a "powered-tool" that was attached or supported on the surface the worker stood on (jumbo drill; raise platform wood; raise platform metal). Vibration measurements were collected at the location where the worker stood to complete the required job task. Background information and a musculoskeletal disorder questionnaire were also collected for each equipment operator.

\section{Results}

Vibration exposure resulting from a primary source exposure had a dominant frequency below 6.3 Hz. However, the dominant frequency recorded from secondary source exposures were predominantly in the 31.5 and $40 \mathrm{~Hz}$ range (Table 1). Two workers indicated they have been diagnosed with white feet and all other workers reported discomfort in their lower limbs. The wooden raise platform and the metal raise platform exposed the workers to vibration levels at the feet that placed them above the ISO 2631-1 health guidance caution zone, when the 8-hour frequency-weighted r.m.s acceleration exposure levels were considered (ISO, 1997). 
Table 1: Vibration characteristics recorded at the feet during the operation of underground mining equipment. Musculoskeletal discomfort reported by the workers is also summarized.

\begin{tabular}{|c|c|c|c|c|}
\hline Machine & Source & $\begin{array}{l}\mathbf{D F}_{\mathbf{z}} \\
(\mathbf{H z})\end{array}$ & $\begin{array}{c}a_{w z} \\
(m / s / s)\end{array}$ & $\begin{array}{c}\text { Reported Musculoskeletal Discomfort } \\
\text { 1=mild discomfort; } 4 \text { = severe discomfort }\end{array}$ \\
\hline Locomotive-1 & Primary & 6.3 & 0.43 & $\begin{array}{l}\text { Neck:1, Lower Back:2, R.Wrist:1, } \\
\text { L.Wrist:1, L.Knee:1, R.Knee:1 }\end{array}$ \\
\hline Locomotive-2 & Primary & 3.15 & 0.36 & L.Knee:1, R.Knee:1, L.Ankle:3, R.Ankle:1 \\
\hline $\begin{array}{l}\text { Jumbo Drill } \\
\text { (1 drill boom) }\end{array}$ & Secondary & 31.5 & 0.16 & $\begin{array}{l}\text { R.Shoulder, R.Wrist 2, L.Wrist:2, L.Feet:1, } \\
\text { R.Feet:1 } \\
\text { Diagnosed with white hands and feet }\end{array}$ \\
\hline $\begin{array}{l}\text { Wooden Raise } \\
\text { Platform } \\
\text { (1 drill operating) }\end{array}$ & Secondary & 40 & 1.1 & $\begin{array}{l}\text { L.Shoulder:2, R.Shoulder:2, L.Elbow:2, } \\
\text { R.Elbow:2, Upper Back:2, Lower Back:2, } \\
\text { L.Wrist:2, R.Wrist:2, Hips\&Thighs:2, } \\
\text { L.Knee:2, R.Knee:2, L.Ankle:2, R.Ankle:2 } \\
\text { Diagnosed with white hands and feet }\end{array}$ \\
\hline $\begin{array}{c}\text { Metal Raise } \\
\text { Platform } \\
\text { (1 drill operating) } \\
\end{array}$ & Secondary & 40 & 1.08 & \multirow{2}{*}{$\begin{array}{l}\text { Worker 1: L.Ankle:1, R.Ankle:1, L.Knee:3, } \\
\text { R.Knee:3, Hips\&Thighs:1, L.Wrist/Hand:2, } \\
\text { R.Wrist/Hand:3, Lower back:3, L.Elbow:1, } \\
\text { R.Elbow:1, Upper back:1, L.Shoulder:2, } \\
\text { R.Shoulder:2, Neck:3 } \\
\text { Worker 2: L.Ankle:2, R.Ankle:2, L.Knee:2, } \\
\text { R.Knee:2, L.Wrist:3, R.Wrist:3, Lower } \\
\text { back:1, Upper back:1 }\end{array}$} \\
\hline $\begin{array}{l}\text { Metal Raise } \\
\text { Platform } \\
\text { (1-drill with “anti- } \\
\text { vibration" leg) }\end{array}$ & Secondary & 40 & 0.8 & \\
\hline
\end{tabular}

\section{Discussion}

Workers standing on the jumbo drill and raise platforms experienced dominant frequency vibration known to be associated with hand-arm vibration syndrome. The jumbo drill operator and one of the raise workers confirmed they have already been diagnosed with white feet. The dominant frequency recorded at the feet of the locomotive operators was in the range associated with "whole-body" health effects. Interestingly, one of the locomotive workers reported greater discomfort in the neck and lower back. Further investigation is warranted to determine long-term health effects resulting from vibration exposure via the feet.

\section{References}

1. Bovenzi, M. (2005). Health effects of mechanical vibration. Giornale Italiano di Medicina del Lavoro ed Ergonomia. 27(1): 58-64.

2. Cooke, J.P. \& Marshall, J.M. (2005). Mechanisms of Raynaud's disease. Vascular Medicine. 10: 293-307.

3. International Organization for Standardization (1997). ISO 2631-1 Mechanical Vibration and Shock - Evaluation of Human Exposure to Whole-Body Vibration - Part 1: General Requirements. Geneva, Switzerland. Reference Number ISO 2631-1:1997(E)

\section{Acknowledgements}

Funding provided by the Centre for Research Expertise for the Prevention of Musculoskeletal Disorders and the Workplace Safety and Insurance Board of Ontario, Canada. 